\title{
Small and Medium Businesses Informatization Managment: Main Trends of Development in Russia
}

\author{
Ushakova T.V. \\ Kazan Federal University, Institute of Management, Economics and Finance, Kazan, 420008, Russia \\ Email address: yours.ccounter@gmail.com
}

Safiullin A.R.

Kazan Federal University, Institute of Management, Economics and Finance, Kazan, 420008, Russia

Strelnik E.U.

Kazan Federal University, Institute of Management, Economics and Finance, Kazan, 420008, Russia

\section{Doi:10.5901/mjss.2014.v5n24p165}

\section{Abstract}

The system architecture of a small business must also provide financial management, personnel, procurement, manufacturing, sales, etc. Due to the fact that in small and medium-sized businesses there are combined functions of ownership and management, information management system must provide accurate and up-to-date information about finance and manufacturing resources. We have reviewed the structure of the Russian market of software products for small and mediumsized businesses and explained the leading position of some companies. We conducted a survey of SEOs of SME and employees of the companies ERP systems vendors, who showed quite a symmetric assessment of development informatization of SME.

Keywords: SME, Product-Centric Midmarket Companies, branch specialization, efficient implementation of the technology, CRM, SAP ERP, 1C Company, accounting statements, implementation of sectoral programs, computer literacy

\section{Introduction}

As world practice shows, the choice of information management system is an extremely difficult and complex task that requires serious inquiry about the organization and clear stating of the requirements to information architecture in the company. Small and medium-sized businesses represent a very significant amount of the economy in different countries, for example, up to $80 \%$ on the number of employed in Japan and about $60 \%$ of GDP in the countries of EC. These figures are rising, and consequently the small business is one of the most important consumers of computer technologies and equipment. Considerable potential in this market stimulates manufacturers to develop specialized software, taking into account the specifics of the SME.

Review shows that the most popular destinations of research informatization of SME are following : impact of implementation ERP systems on decision-making and strategic management of companies [1],[2]; assessment of factors that significantly affect the implementation of ERP systems and project management in it-technology [12]; study of competences required employees SME, which use ERP systems [4]; overview of trends, issues and different aspects of SME informatization in certain countries [5], [10]; IT-outsourcing services for small and medium enterprises and implementation cloud computing.

\section{Theory}

The scope of business does not bring about a reduction in management hierarchy of business processes. The system architecture of a small business must also provide financial management, personnel, procurement, manufacturing, sales, etc. [4]. On the other hand, there are objective peculiarities of small and medium-sized businesses, which define the specific nature of such software products.

1. The most significant feature is the limitedness of financial resources, the low availability of borrowing sources. 
Such companies are limited in their ability of frequent renewal for the manufacturing process of equipment. Due to the fact that in small and medium-sized businesses there are combined functions of ownership and management, information management system must provide accurate and up-to-date information about finance and manufacturing resources [3].

2. Small businesses have a tough industry specialization and they conduct business in conditions of high commercial and financial risks compared with corporations, in this respect separate companies have slight influence on the market environment. Investment in IT-technologies and equipment in this context differs by clear and reasonably required, rigorous approach to the selection of software solutions.

3. In many countries, for SME there are used special tax regulations (France, CIS). This fact carries to additional requirements for information management system, more complex localization in terms of accounting and reporting [12].

Let us see how the above mentioned features influenced on the Russian IT-system market for SME. Limitedness of financial, manufacturing and human resources on the one hand, and the legal requirements for provision of accounting control on the other, explain the situation when the main computer based control module is accounting and preparation of accounting. Implementation of the ERP-systems is not in grassroots, although in the market there is represented a certain range of software products integrated automation management and oriented for the SME segment [2].At the same time, this segment is characterized by the information management architecture and availability of software products created by specialists of the companies. In the recent past, in the limitedness of the market conditions making their own programs was a cheap and effective way for information management. Expenditures connected with the creation and maintenance for such products, if they had not been patented, were treated as operating expenses, making it difficult for them to integrated assessment. High risks of limited service for such software products cause gradual failure for them and commitment to technology with guaranteed service.

The level of automation control within SME depends on the industry specialization. Thus, in particular, the distributive services and retail as a more resource-intensive activity in terms of information service are characterized by more progressive and mastered industry technology. The segment of CRM software products is actively developed with a focus on SME. Modernization of storage technologies allows to solve many organizational and industry technological objectives and to improve business performance.

The development of modern technologies contributes to the emergence of new types of information services for SME. The use of Saas-technologies provides significant financial and technological benefits: reducing the cost of equipment and licenses, increase business flexibility, when access to information is provided from any location with Internet connection, higher information security, because data safety is provided as a separate function of provider [6].

The current standard of the company management is ERP-system, with the principal elements, by Gartner's definition, should be: MRPII; production support, financial accounting; sales management; procurement and SCM ; human resources human resource management [13].

Using ERP-system offers company significant advantages to organize its effective management, accelerate response on the environment changes, improve the quality of customer service. System implementation is an essential cost item for companies, economic effect of these costs should be carefully analyzed. For this kind of assessment is offered to use such indicators as: ROI, TCO, cost-benefits analysis [7]. TCO, cost-benefits analysis. We agree with the concept: the return on investment in ERP-system to enhance the effectiveness of business processes, which it supports. In other words, the effective implementation of the technology is intended for ultimate development of the market position for the company and reaching key performance indicators.

Gartner Consulting evaluates global market ERP-systems for SME using the Magic Quadrant [14]. World market leaders are technologies of SAP Business All-in-One and Microsoft "SAP Business All-in-One" и "Microsoft Dynamics Ax" (Axapta). Ax (Axapta) (Figure 1). There are examples of implementation of technologies such as "Oracle E- Business Suite", "Sage ERP X3", "Scala", "Infor ERP EntERPrise" in the Russian market also. 


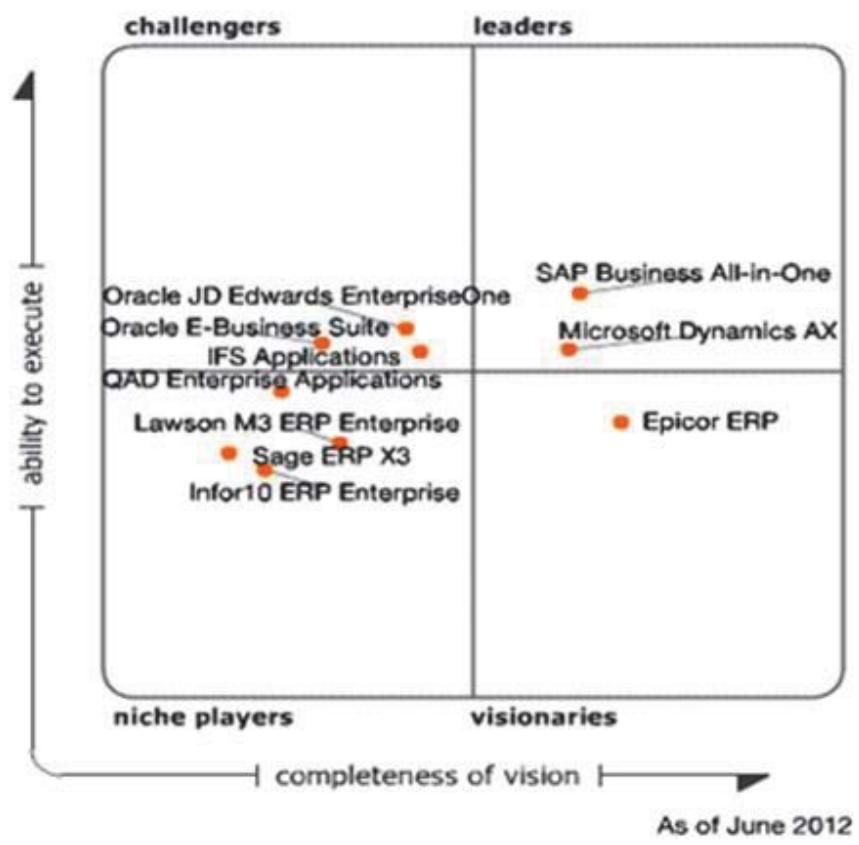

ERP Magic Quadrant for Product-Centric Midmarket Companies Infor In the segment of ERP-products for large businesses leaders in Russia are foreign suppliers of SAP AG, Microsoft, Oracle. These producers are leading the last decade in terms of sales volume. At the same time, in terms of the number of the implemented projects dominates Russian1C company.

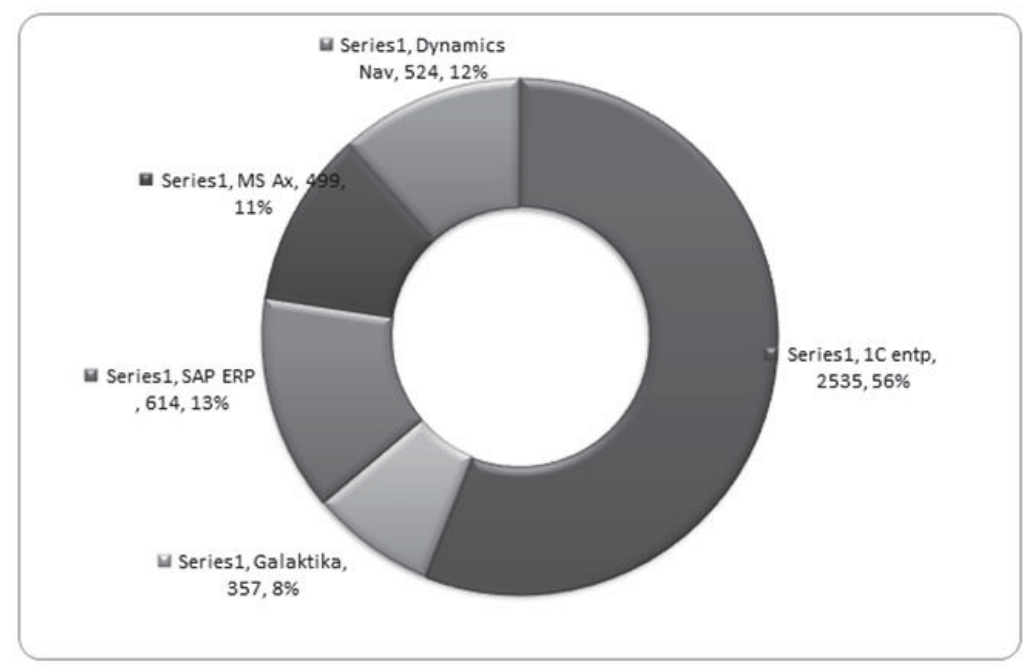

Figure 2. The most widespread ERP-products used in Russia

1C company activity is based on the franchising, the main staff for about 1,000 employees is responsible for developing and updating software products. At the same time in Russia and the CIS, there are over 6500 companies implementers, which employs more than 100 thousand it-specialists.

The leading position provide the interaction of $1 \mathrm{C}$ company with governmental agencies, that determine the electronic format of the accounting control and tax reporting in the Russian Federation. For a long period of time the company specialized in automation of SME within the financial management and accounting statements. This is the main factor, in our opinion, in explaining the leadership of the manufacturer of software for SME. In definitions, used by IDS [USA] analysts , International Data Corporation (IDC)was "unincorporated" information management product. Since the 
introduction of the product line "1C Enterprise Management 8" (2002) the company has been considered as a supplier of ERP-solutions.

\section{Results}

Within the framework of the study on the development trends in the IT-market for SME we conducted a survey among the leaders of 10 companies in this segment, and 10 representatives of the companies - vendors, service providers of SME automation. The main goal of the survey was to identify the general direction of IT-industry within SME segment. CEOs were asked the following questions: Satisfaction with the level of information support of their business management? Intended Changes to the information system of the company that could bring value to their business?

Specialists from IT-companies were asked the following questions: Evaluation score of PC Estimation of level of computer literacy of their clients? What problems are associated with the implementation of ERP-systems within the scope SME? Determination of the potential requirements for ERP-systems by SME companies?

The most common answers can be summarized in the following table.

Table 1. The results of the survey of the CEOs SME companies and employee of it-vendors

\begin{tabular}{|c|c|}
\hline SME CEOS & Vendors \\
\hline $\begin{array}{l}\text { 1. Contentment Information System depends on } \\
\text { industry-specific business processes and features } \\
\text { industry-specific software products. There is no } \\
\text { complaints setting and completion of accounting, } \\
\text { warehouse and HR software. Negative reviews identified } \\
\text { for the implementation of sectoral programs such as 1C } \\
\text { Catering; } 1 \text { C Dental offices; 1C Motor transport. In two } \\
\text { cases out of } 10 \text { stated that their accounting program is } \\
\text { not possible to get the current analytics about the state } \\
\text { inventories for management decision making. }\end{array}$ & $\begin{array}{l}\text { 1. It is impossible to give a clear assessment level of } \\
\text { computer literacy executives SME, based on the results of } \\
\text { testing it-specialists. However, a trend that Executive } \\
\text { Directors of retail and transport companies have great } \\
\text { knowledge and are more susceptible to technological } \\
\text { changes. }\end{array}$ \\
\hline \multirow{2}{*}{$\begin{array}{l}\text { 2. Detected trend that retail companies are interested in } \\
\text { more in online monitoring of sales and interaction with } \\
\text { clients. } \\
\text { In three cases out of ten considered the possibility of } \\
\text { introducing 1C: CRM. } \\
\text { In one out of ten companies discussed contract 1C } \\
\text { hosting service. }\end{array}$} & $\begin{array}{l}\text { 2. There are no problems during the installation of unified } \\
\text { management and accounting software. Difficulties with } \\
\text { industry solutions } 1 C \text {, as well as in companies with complex, } \\
\text { specific business processes. }\end{array}$ \\
\hline & $\begin{array}{l}\text { 3. All vendors support the need for implementation ERP- } \\
\text { systems in small and medium-sized businesses. In this report } \\
\text { they saying about lack of qualified ERP-architects, solution } \\
\text { managers in the implementation of such projects. }\end{array}$ \\
\hline
\end{tabular}

\section{Conclusions}

The most significant feature is the limitedness of financial resources, the low availability of borrowing sources. Such companies are limited in their ability of frequent renewal for the manufacturing process of equipment. Due to the fact that in small and medium-sized businesses there are combined functions of ownership and management, information management system must provide accurate and up-to-date information about finance and manufacturing resources.

The level of automation control within SME depends on the industry specialization. Thus, in particular, the distributive services and retail as a more resource-intensive activity in terms of information service are characterized by more progressive and mastered industry technology. The segment of CRM software products is actively developed with a focus on SME.

In the segment of ERP-products for large businesses leaders in Russia are foreign suppliers of SAP AG, Microsoft, Oracle. These producers are leading the last decade in terms of sales volume. At the same time, in terms of the number of the implemented projects dominates Russian1C company. For a long period of time the company specialized in automation of SME within the financial management and accounting statements. This is the main factor, in our opinion, in explaining the leadership of the manufacturer of software for SME. The leading position provide the interaction of $1 \mathrm{C}$ company with governmental agencies, that determine the electronic format of the accounting control and tax reporting in the Russian Federation now. 
We conducted a survey among the leaders of 10 companies in this segment, and 10 representatives of the companies - vendors, service providers of SME automation. The main goal of the survey was to identify the general direction of IT-industry within SME segment. Identified largely symmetric estimates of development it-segment for small and medium-sized businesses from the directors of the companies and technology vendors. Negative reviews identified for the implementation of sectoral programs. There is the trend that Executive Directors of retail and transport companies have great knowledge and are more susceptible to technological changes.

\section{References}

Henry Teittinen, Jukka Pellipen, Marco Järvernpää (2013), ERP in action - Challenges and benefits for management control in SME context. International Journal of Accounting International Accounting Information Systems, Vol. 14, No.4 pp. 278-296.

Alexandra Kanellou, Charalambos Spathis (2013), Accounting benefits and satisfaction in an ERP environment. International Journal of Accounting International Accounting Information Systems, Vol. 14, No.3 pp. 209-234.

Pedro Ruivoa, Björn Johanssonb, Tiago Oliveiraa,Miguel Netoa(2012) Determinants that influence ERP use and value: cross-country evidence on Scandinavian and Iberian SMEs. Procedia Technology, 5, pp. $354-362$.

Rajiv Malhotra, Cecilia Temponi (2010) Critical decisions for ERP integration: Small business issues. International Journal of Information Management Vol. 30, No.1 pp. 28-37.

Liping Ge, Stefan Voß(2009) ERP application in China: an overview.International Journal of Production Economics, Vol. 122, Issue 1,pp. 501-507.

Sarmad Alshawi, Farouk Missi, Zahir Irani(2011)Organisational, technical and data quality factors in CRM adoption - SMEs perspective.Industrial Marketing Management, Vol. 40, No. 3,pp. 376-383.

Bjorn Johansson, Frantisek Sudzina, Mike Newman (2011) ERP system implementation costs and selection factors of an implementation approach. International Journal of Business Information Systems (IJBIS) 6(1), pp.87-105.

S.C.L. Koh, A. Gunasekaran, T. Goodman (2011) Drivers, barriers and critical success factors for ERPII implementation in supply chains: A critical analysis. The Journal of Strategic Information Systems, Vol. 20, Issue 4,Pages 385-402.

S.F. Huin, L.H.S. Luong, K. Abhary(2003)Knowledge-based tool for planning of entERPrise resources in ASEAN SMEs.Robotics and Computer-Integrated Manufacturing, Vol. 19, No. 5,pp. 409-414

C. Annamalai, T. Ramayah (2011) A review of ERP implementation in India. International Journal of Business and Systems Research, Vol. 5, No.4 pp. 406 - 421

Pedro Ruivo, Tiago Oliveira, Miguel Neto (2014) ExamineERP post-implementation stages of use and value: Empirical evidence from Portuguese SMEs.International Journal of Accounting Information Systems, Vol. 15, No. 2,pp. 166-184.

Pedro Ruivo, Björn Johansson, Tiago Oliveira, Miguel Neto (2013) Commercial ERP Systems and User Productivity: A Study AcrossEuropean SMEs. Procedia Technology, Vol. 9,pp. 84-93.

Mihaela Filofteia Tutunea, Rozalia Veronica Rus(2012) Business Intelligence Solutions for SME's.Procedia Economics and Finance, Vol. 3,pp. 865-870.

Bagautdinova N.G., Khadiullina G.N.,. Shevko N.R, Pratchenko O.V. Condition and Development Characteristics of The Russian Market of Information Technilogies// Mediterranean Journal of Social Sciences.- Vol.5, No12, (2014)-pp.21-26.

Safiullin N.Z., Gafurov I.R., Safiullin L.N., Odintsova U.L. Modern Information Resources in Education// Mediterranean Journal of Social Sciences.- Vol.5, No12, (2014)-pp.113-116.

M. Montgomery. (2012) Magic quadrant for ERP for Product-centric midmarket companies. Available:http://sme.news.sap.com/ files/2011/01/SAP-vol2art5.pdf http://www.1bit.com/news/1c_company_s_ERP_market_share_increased_significantly_in_2011. html 